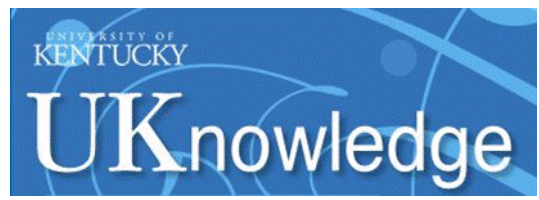

University of Kentucky

UKnowledge

Biosystems and Agricultural Engineering Faculty Publications

\title{
Toward Biochemical Conversion of Lignocellulose On-Farm: Pretreatment and Hydrolysis of Corn Stover In Situ
}

\author{
Alicia A. Modenbach \\ University of Kentucky, alicia.modenbach@uky.edu \\ Sue E. Nokes \\ University of Kentucky, sue.nokes@uky.edu \\ Michael D. Montross \\ University of Kentucky, michael.montross@uky.edu \\ Barbara L. Knutson \\ University of Kentucky, bknutson@engr.uky.edu
}

Follow this and additional works at: https://uknowledge.uky.edu/bae_facpub

Part of the Biochemistry Commons, Bioresource and Agricultural Engineering Commons, Enzymes and Coenzymes Commons, and the Plant Sciences Commons

Right click to open a feedback form in a new tab to let us know how this document benefits you.

\section{Repository Citation}

Modenbach, Alicia A.; Nokes, Sue E.; Montross, Michael D.; and Knutson, Barbara L., "Toward Biochemical Conversion of Lignocellulose On-Farm: Pretreatment and Hydrolysis of Corn Stover In Situ" (2017). Biosystems and Agricultural Engineering Faculty Publications. 218.

https://uknowledge.uky.edu/bae_facpub/218

This Article is brought to you for free and open access by the Biosystems and Agricultural Engineering at UKnowledge. It has been accepted for inclusion in Biosystems and Agricultural Engineering Faculty Publications by an authorized administrator of UKnowledge. For more information, please contact UKnowledge@lsv.uky.edu. 
Toward Biochemical Conversion of Lignocellulose On-Farm: Pretreatment and Hydrolysis of Corn Stover In Situ

\section{Digital Object Identifier (DOI)}

https://doi.org/10.13031/trans.12069

Notes/Citation Information

Published in Transactions of the ASABE, v. 60, issue 4, p. 1025-1033.

(C) 2017 American Society of Agricultural and Biological Engineers

The copyright holder has granted the permission for posting the article here. 


\title{
TOWARD BIOCHEMICAL CONVERSION OF LIGNOCELLULOSE ON-FARM: PRETREATMENT AND HYDROLYSIS OF CORN STOVER IN SITU
}

\author{
A. A. Modenbach, S. E. Nokes, M. D. Montross, B. L. Knutson
}

\begin{abstract}
High-solids lignocellulosic pretreatment using $\mathrm{NaOH}$ followed by high-solids enzymatic hydrolysis was evaluated for an on-farm biochemical conversion process. Increasing the solids loadings for these processes has the potential for increasing glucose concentrations and downstream ethanol production; however, sequential processing at high-solids loading similar to an in-situ on-farm cellulose conversion system has not been studied. This research quantified the effects of high-solids pretreatment with $\mathrm{NaOH}$ and subsequent high-solids enzymatic hydrolysis on cellulose conversion. As expected, conversion efficiency was reduced; however, the highest glucose concentration $\left(40.2 \mathrm{~g} \mathrm{~L}^{-1}\right)$, and therefore the highest potential ethanol concentration, resulted from the high-solids combined pretreatment and hydrolysis. Increasing the enzyme dosage improved cellulose conversion from $9.6 \%$ to $36.8 \%$ when high-solids loadings were used in both unit operations; however, increasing $\mathrm{NaOH}$ loading and pretreatment time did not increase the conversion efficiency. The enzyme-to-substrate ratio had a larger impact on cellulose conversion than the $\mathrm{NaOH}$ pretreatment conditions studied, resulting in recommendations for an on-farm bioconversion system.
\end{abstract}

Keywords. Corn stover, Enzymatic hydrolysis, Enzyme loading, High solids, Low solids, Sodium hydroxide.

$\mathrm{T}$ The potential for recovering energy from lignocellulose has long been recognized by the academic and industrial communities. However, developing a feasible large-scale process to achieve this recovery has proven challenging (Klein-Marcuschamer and Blanch, 2015). Lignocellulose is composed of polymers of glucose (cellulose), mixed carbohydrate polymers consisting predominately of xylose (hemicellulose), and polymers of phenyl-propanoid units (lignin). The structure of lignocellulose is highly recalcitrant to depolymerization (Isroi et al., 2011). The operations thought necessary to recover glucose and xylose from plant biomass include harvesting and storing the plant material, comminution (particle size reduction), pretreatment to improve accessibility to carbohydrates, and hydrolysis (Klein-Marcuschamer and Blanch, 2015). Fuel alcohols are then produced by fermenting the hydrolysate with alcohol-producing microorganisms (Liong et al., 2012). Historically, these operations have been studied in isolation; however, as they are all interdependent, a systematic approach must be employed to optimize the production of energy and minimize environmental impacts from the process (Klein-Marcuschamer and Blanch, 2015).

Submitted for review in August 2016 as manuscript number ES 12069; approved for publication by the Energy Systems Community of ASABE in March 2017.

The authors are Alicia A. Modenbach, ASABE Member, Lecturer, Sue E. Nokes, ASABE Member, Professor and Chair, and Michael D. Montross, ASABE Member, Professor, Department of Biosystems and Agricultural Engineering, and Barbara L. Knutson, Professor, Department of Chemical Engineering, University of Kentucky, Lexington, Kentucky. Corresponding author: Sue Nokes, 128 C.E. Barnhart Building, University of Kentucky, Lexington, KY 40546; phone: 859-218-4328; e-mail: snokes@uky.edu.
Large-scale on-farm production of biofuels is an attractive alternative to a centralized biorefinery because on-farm processing eliminates biomass transport, which is one of the higher-cost operations (Klein-Marcuschamer and Blanch, 2015). Storage, comminution, and pretreatment are the first three unit processes that must be considered when envisioning an on-farm biofuel production scheme. Ideally, on-farm processes would require low capital equipment investments and low energy inputs. One of the major energy sinks associated with biofuel production is product recovery (Jurgens et al., 2012; Singhania, et al., 2009). However, the separation costs decrease markedly with increased product concentration in the fermentation broth (Ezeji et al., 2004). One approach for increasing product concentration during fermentation is to perform the bioconversion at high solids content (Triwahyuni et al., 2015; Banerjee et al., 2012; Viamajala et al., 2010). Advantages of bioconversion at high solids content are increased sugar concentration in the saccharification step and hence higher ethanol concentration in the fermentation broth, as well as reduced capital and operating costs (Banerjee et al., 2010; Humbird et al., 2010; Hodge et al., 2008). Additionally, while interest in the use of high-solids loadings for pretreatment or enzymatic hydrolysis is increasing, few investigations into the integration of the pretreatment and hydrolysis steps at high-solids loadings are available (Rabelo et al., 2014; Larsen et al., 2008; Lau and Dale, 2009).

Systems are considered "high-solids" at solids loadings of $\geq 15 \%$ (w/w), where essentially no free water is available. However, at $>15 \%(\mathrm{w} / \mathrm{w})$ solids, several challenges emerge that are not as apparent at low or moderate solids loadings. For example, the lack of available water in the system and 
inadequate mixing of the solids can limit heat and mass transfer (Viamajala et al. 2010; Singhania et al., 2009). In pretreatment, these limitations can lead to temperature gradients that may result in non-uniform treatment of biomass (Luterbacher et al., 2010). In hydrolysis, these limitations can lead to regions of sub-optimal temperatures and pockets of increased inhibitor concentrations, both of which are detrimental to enzyme activity (Modenbach and Nokes, 2013).

Pretreatment with sodium hydroxide $(\mathrm{NaOH})$ is one of the more attractive pretreatments for on-farm use because it is effective at lower temperatures and pressures than most pretreatments (Modenbach and Nokes, 2014). $\mathrm{NaOH}$ pretreatment results in several structural modifications of lignocellulose that are beneficial for enzymatic hydrolysis (Modenbach and Nokes, 2014; Cui et al., 2012; Cheng et al., 2010; Xu et al., 2010) by breaking bonds linking the protective lignin barrier with hemicellulose. Depending on the pretreatment conditions, lignin is more or less solubilized, and degradation of the hemicellulose fraction may occur. Sodium hydroxide pretreatment also swells the lignocellulose particles, leading to an increase in surface area and greater enzymatic accessibility to the cellulose fraction (Hendriks and Zeeman, 2009). Additionally, a decrease in the degree of polymerization and crystallinity of the cellulose is likely, which is linked to increased enzymatic digestibility of the polysaccharide (Eronen et al., 2009; Mittal et al., 2011). The true test of the efficacy of pretreatment, therefore, is the success of the subsequent enzymatic hydrolysis.

Several studies have measured the effectiveness of varying $\mathrm{NaOH}$ pretreatment conditions on cellulose conversion of agricultural residues (Sills and Gossett, 2012a; Cui et al., 2012; Wan et al., 2011; Cheng et al., 2010; Gupta and Lee, 2010; Duguid et al., 2009) and were summarized by Modenbach and Nokes (2014); however, most of these studies were conducted at low-solids loadings. Gupta and Lee (2010) reported a cellulose conversion of $99.8 \%$ from corn stover following pretreatment at $10 \%(\mathrm{w} / \mathrm{w})$ solids with $50 \mathrm{~g} \mathrm{NaOH}$ per $100 \mathrm{~g}$ solids at $60^{\circ} \mathrm{C}$ for $24 \mathrm{~h}$. However, the temperature and $\mathrm{NaOH}$ loading were some of the highest reported in the literature. Another study reported a cellulose conversion of $80 \%$ from corn stover following pretreatment at $5 \%(\mathrm{w} / \mathrm{w})$ solids with $20 \mathrm{~g} \mathrm{NaOH}$ per $100 \mathrm{~g}$ solids at $25^{\circ} \mathrm{C}$ for $24 \mathrm{~h}$ (Sills and Gossett, 2012a). A study investigating high-solids $(20 \% \mathrm{w} / \mathrm{w}) \mathrm{NaOH}$ pretreatment of rice straw reported cellulose conversions of $35 \%$ to $40 \%$ when the pretreatment was performed with $4 \mathrm{~g} \mathrm{NaOH}$ per $100 \mathrm{~g}$ solids at $55^{\circ} \mathrm{C}$ for 2 to $3 \mathrm{~h}$ (Cheng et al., 2010). Subsequent enzymatic hydrolysis performed in each of these studies was conducted at lowsolids loadings $(<4 \% \mathrm{w} / \mathrm{w})$.

$\mathrm{NaOH}$ pretreatment is strongly alkaline, with a $\mathrm{pH}$ of $\sim 13$ to 14 , much higher than the optimal $\mathrm{pH}(\sim 4.8)$ of cellulase enzymes. Neutralization of the biomass following pretreatment is crucial for optimal performance of the enzymes during hydrolysis. Typically, large volumes of water (10 to 20 volumes) are used to rinse the pretreated biomass (Sills and Gossett, 2012a, 2012b; Cheng et al., 2010; Banerjee et al., 1995). One of the objectives of working with high-solids loadings is to reduce the amount of water consumed in the conversion process, so extensively washing biomass following pretreatment to obtain a neutral $\mathrm{pH}$ is counterproductive.
Enzymatic hydrolysis is often identified as the rate-limiting step in lignocellulosic conversion (Jørgensen et al., 2007a). The release rate of glucose slows over time during enzymatic hydrolysis. The use of high-solids loadings in enzymatic hydrolysis has aided in producing a more concentrated glucose product (Jørgensen et al., 2007b), but the reduction in glucose release rate over time is more pronounced, likely caused by the inhibition of enzymes by higher concentrations of glucose and other inhibitory products. Even with these limitations, the use of high-solids loadings in enzymatic hydrolysis is still regarded as a promising solution for developing a more economically feasible process (Triwahyuni et al., 2015; Banerjee et al., 2011, 2012).

Few studies have focused on enzymatic hydrolysis conditions, such as solids loadings and enzyme dosages, using $\mathrm{NaOH}-$ pretreated corn stover (Zhang et al., 2012; Chen et al., 2009). One study reported cellulose conversions of 50\% to $80 \%$ from $\mathrm{NaOH}$-pretreated corn stover (pretreated at $12.5 \%$ solids) then hydrolyzed using enzyme dosages of 7 to $20 \mathrm{FPU} \mathrm{g}^{-1}$ solids and $8 \%(\mathrm{w} / \mathrm{w})$ solids loadings during hydrolysis (Chen et al., 2009). Another study conducted by Zhang et al. (2012) used a fed-batch approach to achieve a final solids loading of $30 \%(\mathrm{w} / \mathrm{w})$ in the hydrolysis reaction. Cellulose conversions reached $39 \%$ and $55 \%$ for wheat straw and sugarcane bagasse, respectively. $\mathrm{NaOH}$ pretreatment ( $4 \mathrm{~g} \mathrm{NaOH}$ per $100 \mathrm{~g}$ biomass) was conducted at $5 \%(\mathrm{w} / \mathrm{w})$ solids.

Because of the large interactions between the pretreatment and enzymatic hydrolysis conditions, including substrate type, substrate preparation, and solids loadings during each processing stage, a systematic approach is needed to identify an optimal system for on-farm processing, rather than optimizing individual stages of the process. Simply recombining process stages that have been optimized independently does not reliably result in an optimal system (Singhania et al., 2009).

The objective of this study was to quantify the combined effects of $\mathrm{NaOH}$ pretreatment and enzymatic hydrolysis on cellulose conversion from corn stover when both unit operations are performed at high solids, such as envisioned for an on-farm biomass conversion process. Control treatments involved both high and low solids contents at each process stage for comparison. To date, this is the first known comprehensive study on the combined effects of solids loadings for pretreating and saccharifying $\mathrm{NaOH}$-pretreated corn stover.

\section{MATERials AND Methods}

\section{SUBSTRATE}

Corn stover (CS) was collected directly from the field at the Woodford County Animal Research Center (38.084716 ${ }^{\circ}$ $\left.\mathrm{N}, 84.726672^{\circ} \mathrm{W}\right)$ in Woodford County, Kentucky, in September 2010. The corn (P1253 Pioneer) had been planted using conventional tillage practices in April 2010. Stover is composed of the above-ground material other than grain (MOG). After collection, the samples were prepared for laboratory storage by drying at $45^{\circ} \mathrm{C}$ for $24 \mathrm{~h}$ in an oven and ground to $\leq 0.5 \mathrm{~cm}$ with a Thomas Wiley rotary mini-mill. 


\section{COMPOSITION OF CORN STOVER}

Laboratory Analytical Procedures (LAP) established by the National Renewable Energy Laboratory (NREL) were used to determine total solids, structural carbohydrates, soluble and insoluble lignin, and ash of raw and pretreated biomass (Sluiter et al., 2005, 2008a, 2008b). HPLC was used to measure the sugars derived from cellulose and hemicellulose (glucose, xylose, arabinose, mannose, and galactose).

\section{HPLC ANALYSIS}

A Dionex U3000 HPLC system equipped with a Bio-Rad Aminex HPX-87P column and Micro-Guard de-ashing column was used and operated at $78^{\circ} \mathrm{C}$ with deionized water as the mobile phase at a flow rate of $0.45 \mathrm{~mL} \mathrm{~min}^{-1}$. The sample components were detected with a Shodex-101 refractive index detector.

\section{Sodium Hydroxide Pretreatment}

Sodium hydroxide pretreatment was performed according to Duguid et al. (2009) with some modifications. Weighed samples of dried, ground corn stover $(5 \mathrm{~mm})$ were placed in $500 \mathrm{~mL}$ Erlenmeyer flasks in the amount necessary to obtain a solids loading of $5 \%$ or $20 \%(\mathrm{w} / \mathrm{v})$. The dry samples were autoclaved on a liquid cycle at $121^{\circ} \mathrm{C}$ for $30 \mathrm{~min}$ to ensure no loss of biomass due to microbial contamination during pretreatment. The flasks were allowed to cool to room temperature prior to equilibration at the selected pretreatment temperature. Four experiments were conducted using $\mathrm{NaOH}$ pretreatments. For the initial screening, $20 \mathrm{~g} \mathrm{NaOH}$ per $100 \mathrm{~g} \mathrm{CS}$ was used to pretreat corn stover at $5 \%$ and $20 \%$ solids content for $24 \mathrm{~h}$. The second experiment examined $\mathrm{NaOH}$ loadings and pretreatment times using three levels of $\mathrm{NaOH}$ loading $(4,10$, and $20 \mathrm{~g} \mathrm{NaOH}$ per $100 \mathrm{~g} \mathrm{CS})$ and at 2 and $24 \mathrm{~h}$ pretreatment times on corn stover pretreated at $20 \%(\mathrm{w} / \mathrm{v})$ solids. These loading and treatment times were selected based on appropriateness for on-farm use from a thorough literature review (Duguid et al., 2009; Sills and Gossett, 2012b). The conditions for the third experiment were selected based on the previous study's results; corn stover at $5 \%(\mathrm{w} / \mathrm{v})$ solids was pretreated with $4 \mathrm{~g} \mathrm{NaOH}$ per $100 \mathrm{~g} \mathrm{CS}$ for $2 \mathrm{~h}$. The final experiment was conducted on corn stover pretreated at $10 \mathrm{~g} \mathrm{NaOH}$ per $100 \mathrm{~g} \mathrm{CS}$ for $24 \mathrm{~h}$ in order to mimic conditions used in a study we wished to replicate as a check on our hypothesis explaining the results seen in previous experiments. All samples were placed in a $25^{\circ} \mathrm{C}$ shaking incubator set to $150 \mathrm{rpm}$.

\section{PH ADJUSTMENT}

Two methods were compared for neutralizing the alkaline $\mathrm{pH}$ resulting from $\mathrm{NaOH}$ pretreatment. The first method was to wash the pretreated corn stover (PCS) with DI water (10 to 20 volumes) while vacuum filtering until a neutral $\mathrm{pH}$ was achieved in the biomass. The $\mathrm{pH}$ was quantified using $\mathrm{pH}$ paper applied to the biomass. The second method used the volume of concentrated glacial acetic acid calculated to neutralize the $\mathrm{pH}$ based on of the volume of $\mathrm{NaOH}$ used during pretreatment. The acetic acid was added to a reduced amount of wash water (3 to 5 volumes). Following both methods, the samples were dried in a $45^{\circ} \mathrm{C}$ oven for $24 \mathrm{~h}$. The pretreated corn stover was stored at $4^{\circ} \mathrm{C}$ until further use, typically $24 \mathrm{~h}$ or less.

\section{ENZYME}

The enzyme system used consisted of crude cellulase liquid from Trichoderma reesei (Celluclast 1.5L, Novozyme) supplemented with $\beta$-glucosidase from Aspergillus niger (Novozyme 188). Both enzymes were purchased from Sigma-Aldrich. Enzyme activity was determined using LAP-006 established by NREL (Adney and Baker, 1996), and protein content was determined using a total protein assay kit (TP0300, Sigma-Aldrich) based on the Peterson method of protein determination (Peterson, 1977).

\section{ENZYMATIC HYDROLYSIS}

Enzymatic hydrolysis was performed according to an NREL LAP (Selig et al., 2008), with some modifications. Pretreated biomass was added at the desired solids loading $(5 \%$ or $20 \%)$ on a weight basis. Cellulase was added to achieve the desired enzyme loading (varied by treatment) and was supplemented with $\beta$-glucosidase at ratio of 2:1 CBU to FPU (where CBU and FPU are cellobiase units and filter paper units, respectively). Following hydrolysis, the samples were immediately transferred to a boiling water bath for $5 \mathrm{~min}$ and then immediately placed in an ice bath to cool. Subsamples of the slurries were collected and placed in $15 \mathrm{~mL}$ centrifuge tubes. The slurry samples were diluted 10-fold with DI water, mixed well, and centrifuged. Samples of the liquid fraction were then collected, diluted, and analyzed by HPLC.

\section{ENZYME LOADING IN ENZYMATIC HYDROLYSIS}

Two separate experiments were performed to investigate enzyme loading effects as a function of solids loading. First, a low and high enzyme dosage (5.2 and $60 \mathrm{FPU} \mathrm{g}^{-1}$ solids, respectively) was applied to pretreated corn stover. To further investigate results from the high and low enzyme loading experiments, an additional experiment was conducted using enzyme loadings of $15,30,45$, and $60 \mathrm{FPU} \mathrm{g}^{-1}$ solids.

\section{Calculation of Cellulose Conversion}

Cellulose conversion is typically calculated as the ratio between the amount of glucose (and sometimes cellobiose) released during hydrolysis to the theoretical amount of glucose in the substrate. This calculation is based on several assumptions: (1) the specific gravity is the same $\left(1.0 \mathrm{~g} \mathrm{~mL}^{-1}\right)$ for all components in the reaction, (2) the volume of the liquid is equivalent to the volume of the hydrolysis slurry, and (3) the volume of the liquid remains constant throughout the entire reaction. However, these assumptions do not necessarily hold true at high-solids loadings. By diluting the sample 10-fold following enzymatic hydrolysis at high solids, cellulose conversions can be calculated according to Kristensen et al. (2009a, 2009b) with equation 1:

Cellulose conversion $(\%)=$

$$
\frac{[\mathrm{Glu}]+1.0526 \times[\mathrm{Cel}]}{1.111 \times F_{c} \times D M} \times 100
$$

where $[\mathrm{Glu}]$ and $[\mathrm{Cel}]$ are the glucose and cellobiose concentrations $\left(\mathrm{g} \mathrm{L}^{-1}\right)$, respectively, 1.0526 and 1.111 are conversion factors accounting for the water molecule required 
to hydrolyze glucose and cellobiose from cellulose, $F_{c}$ is the fraction of cellulose in the corn stover, and $D M$ is the initial dry matter solids loading $\left(\mathrm{g} \mathrm{L}^{-1}\right)$.

\section{RESULTS AND DISCUSSION}

\section{Effects of Solids LoAding in Pretreatment AND ENZYMATIC HYDROLYSIS}

Table 1 presents the corn stover composition when raw, pretreated at low solids $(5 \% \mathrm{w} / \mathrm{v})$, and pretreated at high solids $(20 \% \mathrm{w} / \mathrm{v})$. The highest reduction in lignin occurred in the low solids treatment, decreasing from $18.9 \%$ in the raw feedstock to $12.8 \%$ in the low-solids pretreated feedstock. The percent lignin in the high-solids pretreatment appears to have increased, but this is likely an artifact of the increased variability seen when working with high solids. What can be safely assumed is that pretreatment in high solids did not result in a measureable reduction in lignin content in absolute amount. It is important to note that although the percent glucose content increased, the amount of actual glucose was constant (numerator remained constant; Modenbach and Nokes, 2014) because when compared to samples that were not pretreated or were pretreated under other conditions, the total amount of available material decreased by removal of

Table 1. Composition of biomass in the raw state following $\mathrm{NaOH}$ pretreatment $(20 \mathrm{~g} \mathrm{NaOH}$ per $100 \mathrm{~g}$ corn stover) at low solids $(5 \% \mathrm{w} / \mathrm{w})$, and high solids $(20 \% \mathrm{w} / \mathrm{w})$. Values are means (with standard deviations in parentheses).

\begin{tabular}{cccc}
\hline Component $^{[\mathrm{a}]}$ & Raw & Low Solids & High Solids \\
\hline Glu (\%) & $37.9(0.5)$ & $48.4(0.1)$ & $44.4(1.1)$ \\
Xyl (\%) & $17.8(0.4)$ & $22.7(1.2)$ & $17.0(0.3)$ \\
Ara (\%) & $2.6(0.1)$ & $4.4(0.3)$ & $1.7(0.5)$ \\
Man (\%) & $0.4(0.0)$ & $0.0(0.0)$ & $2.3(0.3)$ \\
Gal (\%) & $0.8(0.1)$ & $0.5(0.0)$ & $0.3(0.1)$ \\
AIL (\%) & $18.9(0.3)$ & $12.8(0.3)$ & $22.5(5.4)$ \\
ASL (\%) & $2.2(0.0)$ & $1.1(0.1)$ & $1.2(0.0)$ \\
Ash (\%) & $4.8(0.2)$ & $3.3(0.1)$ & $10.1(1.2)$ \\
Other (\%) & 14.6 & 6.8 & 0.5 \\
\hline [a] Values are noted as weight of component per weight of total biomass \\
in percent: Glu = glucose, Xyl= xylose, Ara = arabinose, Man = man- \\
nose, Gal = galactose, AIL = acid-insoluble lignin, and ASL = acid- \\
soluble lignin.
\end{tabular}

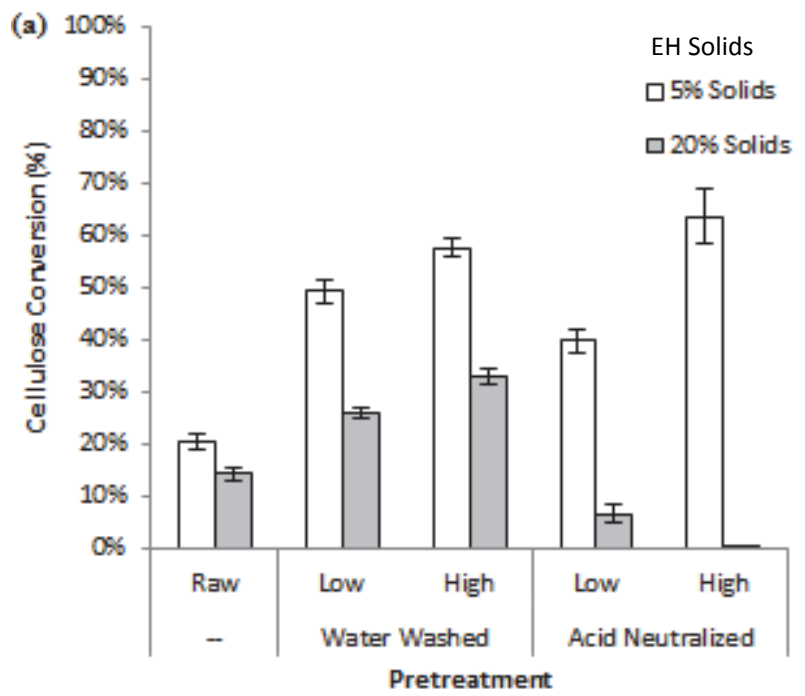

components from the original sample (smaller denominator).

Figure 1 presents the results comparing low (5\%) and high $(20 \%)$ solids loadings in $\mathrm{NaOH}$ pretreatment $(20 \mathrm{~g}$ $\mathrm{NaOH}$ per $100 \mathrm{~g} \mathrm{CS}$ at $25^{\circ} \mathrm{C}$ for $24 \mathrm{~h}$ ) and enzymatic hydrolysis (5.2 $\mathrm{FPU} \mathrm{g}^{-1}$ solids at $50^{\circ} \mathrm{C}$ for $72 \mathrm{~h}$ ) in units of g glucose $\mathrm{g}^{-1}$ biomass expressed as a percent and in $\mathrm{g} \mathrm{L}^{-1}$ as hydrolyzed. The raw corn stover data exemplify the advantages of hydrolyzing in high-solids systems compared to low-solids systems at the on-farm scale: a higher concentration of glucose in the hydrolysate $\left(13.7 \mathrm{~g} \mathrm{~L}^{-1}\right.$ at $20 \%$ solids versus $4.4 \mathrm{~g} \mathrm{~L}^{-1}$ for the $5 \%$ solids hydrolysis). The trade-off is in conversion inefficiencies that occur as the solids loading increases ( $14.1 \%$ cellulose conversion in the $20 \%$ solids system versus $20.5 \%$ in the $5 \%$ solids system).

Similar trends occurred in the other treatments. Considering only the g glucose $\mathrm{g}^{-1}$ biomass conversion efficiency, the high-solids pretreatment followed by low-solids hydrolysis would be the system selected $(57.4 \%$ conversion for waterwashed biomass following $\mathrm{NaOH}$ pretreatment or $63.5 \%$ conversion for acid-neutralized pretreated corn stover). However, there are at least two problems with this selection when considering on-farm conversion strategies: (1) multiple reaction vessels would be needed for processing if the solids content is lowered between pretreatment and hydrolysis, and (2) the final glucose concentration is too low to produce a feasible concentration of alcohol to allow economical alcohol recovery. By contrast, the water-washed highsolids treatment for both the pretreatment and hydrolysis requires only one vessel for processing and results in a higher concentration of glucose $\left(40.2 \mathrm{~g} \mathrm{~L}^{-1}\right)$.

Figure 1 also shows that cellulose conversion was impacted in some cases by the change in neutralization methods from all water washing to acetic acid neutralization with reduced water washing. The only treatment that was unaffected was the high-solids pretreatment and low-solids hydrolysis. One hypothesis for this observed decrease in cellulose conversion is that when acids react with bases, the main products that form are water and salts, which in this case

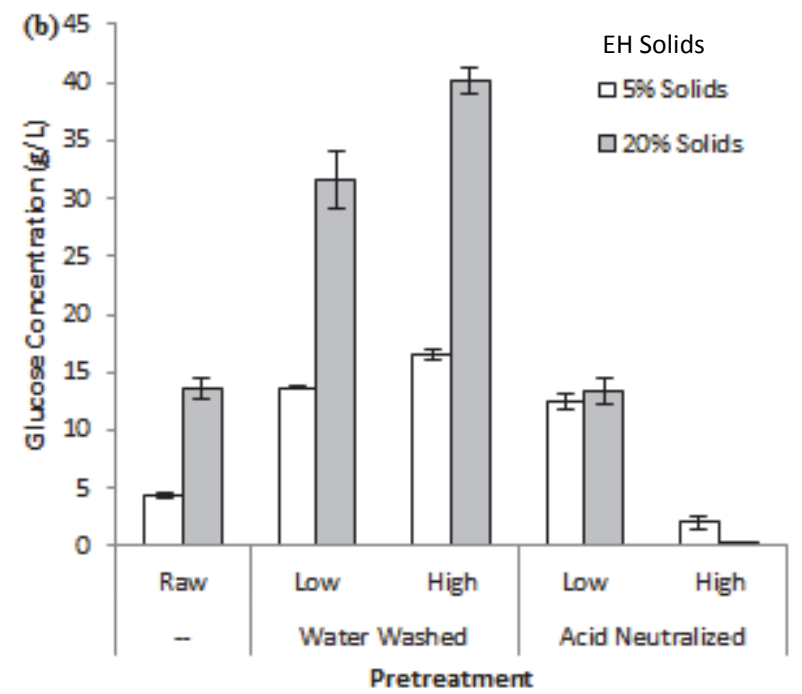

Figure 1. Cellulose conversion of corn stover pretreated at $5 \%$ and $20 \%$ solids loadings and subsequently hydrolyzed at $5 \%$ and $20 \%$ solids loadings: (a) cellulose conversion and (b) glucose values in $\mathrm{g} \mathrm{L}^{-1}$ as hydrolyzed. Pretreatment was performed using $20 \mathrm{~g}$ NaOH per $100 \mathrm{~g} \mathrm{CS}$ at $25^{\circ} \mathrm{C}$ for $24 \mathrm{~h}$. Enzymatic hydrolysis was performed using $5.2 \mathrm{FPU} \mathrm{g}^{-1}$ solids at $50^{\circ} \mathrm{C}$ for $72 \mathrm{~h}$. Error bars indicate standard deviations. 
would be sodium acetate. Actual sodium acetate concentrations were not measured in this study, but based on the amount of acetic acid added during the washing step, as much as 43 to $130 \mathrm{mmol}$ sodium acetate $\mathrm{L}^{-1}$ may have been present. Additionally, the $\mathrm{pH}$ was very high initially ( $\sim 13$ to 14). When $\mathrm{pH}$ is higher than 5.5 , sodium acetate tends to dissociate into its two ionic constituents.

Residual salts (and their ionic constituents) are possible causes for the reduced glucose release in enzymatic hydrolysis for the acid-neutralized treatments. One study found that the production of cellulase by Bacillus coagulans and the subsequent hydrolysis of cellulose slowed as the acetate ion concentration increased (Romsaiyud et al., 2009). Cellulase production $\left(4 \mathrm{U} \mathrm{L}^{-1}\right)$ and cellulose hydrolysis were still measurable at an acetate concentration of $10 \mathrm{mmol} \mathrm{L}^{-1}$, but cellulase production slowed by as much as $75 \%$ to $\sim 1 \mathrm{U} \mathrm{L} \mathrm{L}^{-1}$ at $30 \mathrm{mmol} \mathrm{L}^{-1}$ acetate and was completely eliminated at $60 \mathrm{mmol} \mathrm{L}^{-1}$ acetate.

The highest cellulose conversions observed in these experiments were $45 \%$ to $65 \%$, which are quite low when compared to cellulose conversions following other intensive pretreatments (i.e., dilute acid and steam explosion) that can reach conversions of $>90 \%$. However, these results are consistent with other studies that used $\mathrm{NaOH}$ for pretreating biomass at high solids (Cheng et al., 2010; Cui et al., 2012). We intentionally selected a low-input pretreatment that would be feasible on-farm, knowing that conversion efficiency would be sacrificed to gain practicality in the pretreatment.

A reduction in percent cellulose conversion to glucose as solids loadings are increased in enzymatic hydrolysis was seen in this study (fig. 1a) and has been seen in other studies (Kristensen et al., 2009a, 2009b; Cara et al., 2007; Jørgensen et al., 2007b). This decrease in conversion yields with increasing solids loadings is referred to as the solids effect (Kristensen et al., 2009a, 2009b). However, we contend that, for on-farm conversion, the increase in hydrolysate glucose concentration in high solids (fig. 1b) outweighs the negative aspects of the solids effect.

\section{Effects of NaOH LoAding in Pretreatment}

Figure 2 presents the effects of $\mathrm{NaOH}$ concentration in high-solids pretreatment of corn stover when followed by acid-neutralization and enzymatic hydrolysis at both low and high solids. There is a marked difference between hydrolysis at low and high solids, which is consistent with the lower conversion in high solids when using acid neutralization (fig. 1). Among the low-solids hydrolysis treatments, $10 \mathrm{~g}$ $\mathrm{NaOH}$ per $100 \mathrm{~g}$ CS was statistically equal to $20 \mathrm{~g} \mathrm{NaOH}$ per $100 \mathrm{~g}$ CS when treated for $24 \mathrm{~h}$, and they were both higher than the $4 \mathrm{~g} \mathrm{NaOH}$ per $100 \mathrm{~g} \mathrm{CS}$. For $2 \mathrm{~h}$ pretreatment, $4 \mathrm{~g} \mathrm{NaOH}$ per $100 \mathrm{~g} \mathrm{CS}$ resulted in the highest percent conversion.

Based on trends typically observed for theoretical glucose yields from enzymatic hydrolysis, an increase in yields was expected as the pretreatment conditions became more severe (i.e., longer time and higher $\mathrm{NaOH}$ loading). However, in this study, the effects of pretreatment severity were time dependent (fig. 2). For samples pretreated for $2 \mathrm{~h}$, the glucose

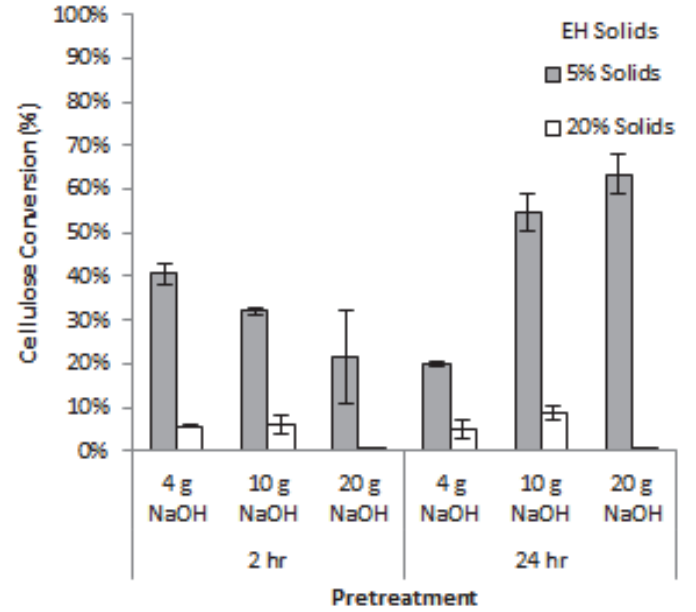

Figure 2. Cellulose conversion of corn stover pretreated at $20 \%$ solids loadings at $25^{\circ} \mathrm{C}$, acid neutralized, and subsequently hydrolyzed at $5 \%$ and $20 \%$ solids loadings. Pretreatment was performed using 4,10 , or $20 \mathrm{~g} \mathrm{NaOH}$ per $100 \mathrm{~g} \mathrm{CS}$ at $25^{\circ} \mathrm{C}$ for 2 or $24 \mathrm{~h}$. Enzymatic hydrolysis was performed using $5.2 \mathrm{FPU} \mathrm{g}^{-1}$ solids at $50^{\circ} \mathrm{C}$ for $72 \mathrm{~h}$. Error bars indicate standard deviations.

yields decreased or remained relatively constant with increasing $\mathrm{NaOH}$ loading, while samples pretreated for $24 \mathrm{~h}$ resulted in increased glucose yields with increasing $\mathrm{NaOH}$ loading. The amount of time and $\mathrm{NaOH}$ applied during pretreatment directly affects a number of factors, including cellulose availability (the amount of theoretical glucose present), cellulose accessibility (the amount of glucose actually accessible to the enzymes for hydrolysis), and optimum processing conditions. Time and $\mathrm{NaOH}$ loading interact and impact the structure by breaking lignin-carbohydrate bonds and causing the lignocellulose particles to expand (Modenbach and Nokes, 2014). It is also important to note that $\mathrm{NaOH}$ is degraded during the pretreatment process from the resulting ester-bond cleavage between the lignin and carbohydrate fractions. Unreacted $\mathrm{NaOH}$ can impact the operating conditions of the subsequent downstream processing steps if the lignocellulose material is not handled appropriately. According to Sills and Gossett (2012a), the amount of $\mathrm{NaOH}$ reacted increased with $\mathrm{NaOH}$ loading, with as much as $7 \mathrm{~g}$ $\mathrm{NaOH}$ per $100 \mathrm{~g}$ TS reacted when corn stover was pretreated with a NaOH loading of $20 \mathrm{~g} \mathrm{NaOH}$ per $100 \mathrm{~g}$ TS for $24 \mathrm{~h}$. Unreacted $\mathrm{NaOH}$ and $\mathrm{NaOH}$ ions could then be transported into the enzymatic hydrolysis reaction, which could shift conditions away from the optimum for the enzymes, thus negatively impacting the glucose yield.

Compositional data from this study do not support an increased degradation of lignin or cellulose for corn stover pretreated at all $\mathrm{NaOH}$ loadings examined. Similar lignin $(22 \%)$ and cellulose $(40 \%)$ contents were observed for samples pretreated with $4 \mathrm{~g} \mathrm{NaOH}$ per $100 \mathrm{~g}$ TS as pretreatment time increased from 2 to $24 \mathrm{~h}$ (data not shown). Cellulose is very stable at low $\mathrm{NaOH}$ concentrations, and this result is consistent with findings reported in the literature (Cui et al., 2012; Sills and Gossett, 2012a). However, for the $4 \mathrm{~g} \mathrm{NaOH}$ per $100 \mathrm{~g}$ TS NaOH pretreatment, $50 \%$ less glucose was released during low-solids hydrolysis (quantified as percent cellulose conversion) for $24 \mathrm{~h}$ pretreatment $(20 \%$ cellulose conversion) as compared to $2 \mathrm{~h}$ pretreatment ( $40 \%$ cellulose 
conversion), which indicates that cellulose accessibility was impacted with increased time, since cellulose availability did not change based on feedstock composition (data not shown).

Lastly, compositional data support an apparent decrease in cellulose content from $49 \%$ to $44 \%$ for corn stover pretreated with $20 \mathrm{~g} \mathrm{NaOH}$ per $100 \mathrm{~g}$ TS as time increased from 2 to $24 \mathrm{~h}$. Again, this reduction in percent cellulose available at higher $\mathrm{NaOH}$ loadings and/or increased pretreatment times is consistent with findings reported in the literature, and higher cellulose availability has been shown to translate to reduced glucose yields upon saccharification (Cui et al., 2012; Sills and Gossett, 2012a).

\section{EFFECTS OF ENZYME LOADING IN HYDROLYSIS}

The effects of enzyme loading in hydrolysis were examined to determine whether higher enzyme applications could overcome the low conversion of cellulose observed in highsolids hydrolysis systems. Only corn stover pretreated at high-solids loadings was used for this investigation. Figure 3 shows conversion of cellulose for low and high enzyme applications to hydrolysis reactions loaded with 5\% and $20 \%$ solids (pretreatment at 20\% solids). Cellulose conversion decreased significantly with increasing solids loadings (40.6\% to $9.6 \%$ ) for the low-dose enzyme application, which was further investigated and is discussed later (fig. 4). However, the opposite was observed for the high-dose enzyme application ( $28.9 \%$ in $5 \%$ solids to $36.8 \%$ in $20 \%$ solids), which is hypothesized to be a result of the higher enzyme-to-substrate ratio negating the diffusion limitations typically observed with high-solids systems, allowing hydrolysis to progress further.

The lower cellulose conversion at a loading of $60 \mathrm{FPU} \mathrm{g}^{-1}$ solids compared to $5.2 \mathrm{FPU} \mathrm{g}^{-1}$ solids on the $5 \%$ solids loading was initially inexplicable. Selig et al. (2012) reported similar results, and they demonstrated that soluble species found in enzyme preparations can significantly reduce the availability of water, which can negatively impact enzymatic hydrolysis, resulting in lower cellulose conversion. The soluble species

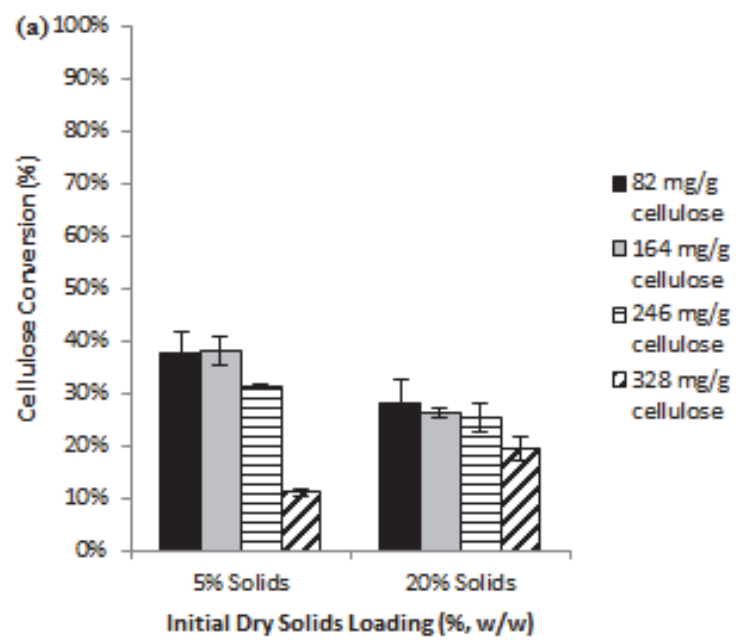

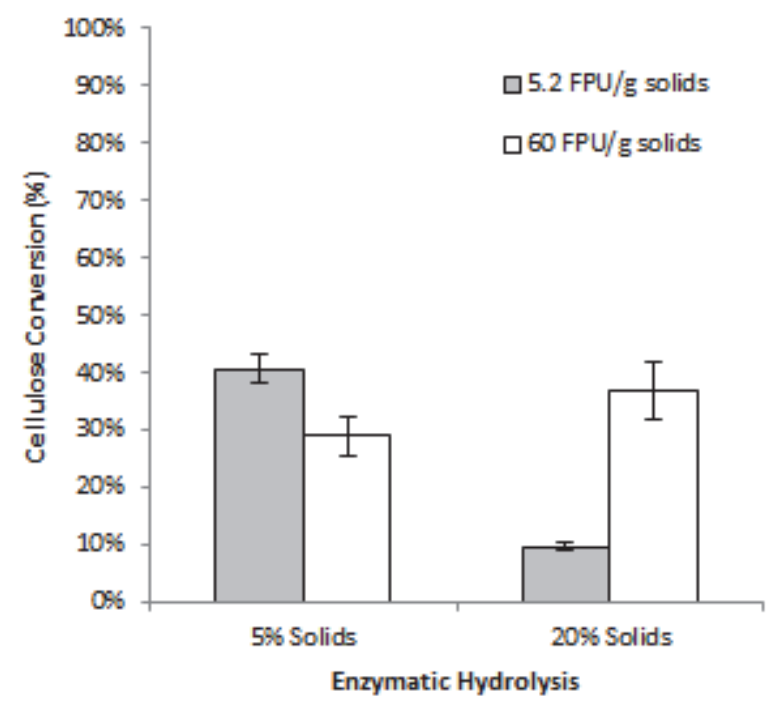

Figure 3. Cellulose conversion of corn stover at $5 \%$ and $20 \%$ solids loadings with low or high enzyme applications. Corn stover was pretreated at $20 \%(\mathrm{w} / \mathrm{v})$ solids with $4 \mathrm{~g} \mathrm{NaOH}$ per $100 \mathrm{~g} \mathrm{CS}$ for $2 \mathrm{~h}$ at $25^{\circ} \mathrm{C}$, acid neutralized, and subsequently hydrolyzed at $50^{\circ} \mathrm{C}$ for $72 \mathrm{~h}$. Error bars indicate standard deviations.

include the soluble enzyme systems and other components found in commercial cellulase preparations, such as fermentation by-products, stabilizers, and preservatives. Selig et al. (2012) also determined that increasing the non-hydrolyzable insoluble solids in the enzyme preparation did not appear to affect the overall cellulose conversion. Selig et al. (2012) confirmed these results by purifying commercial cellulase preparations and applying different enzyme loadings ( 1 to $50 \mathrm{mg}$ protein $\mathrm{g}^{-1}$ cellulose) to $5 \%$ and $20 \%$ initial dry solids loadings (Sigmacel 50 cellulose). Cellulose conversion for the two solids loadings increased with increasing purified enzyme loadings when the inactive soluble components of the enzyme systems were removed. Furthermore, upon addition of increasingly concentrated non-enzymatic components that were previously removed during purification of the commercial enzyme preparation, a significant decline in cellulose conversion

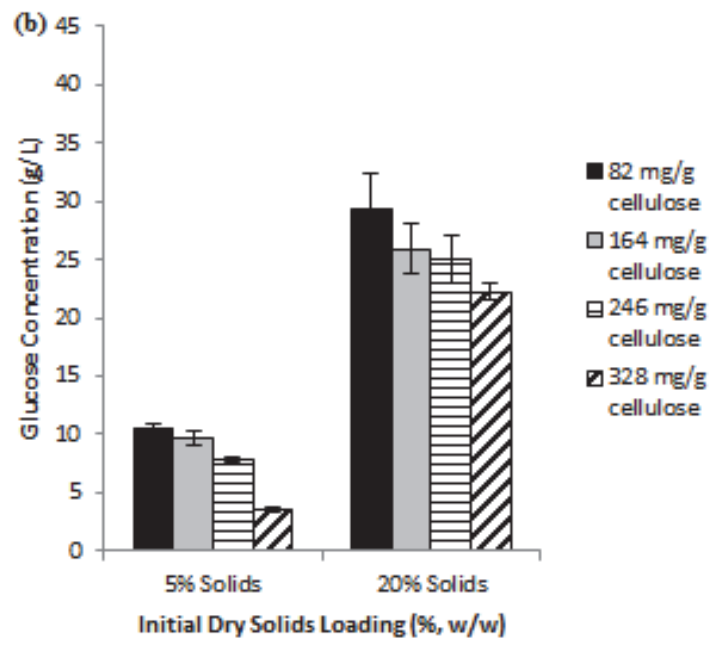

Figure 4. Cellulose conversion of corn stover at $5 \%$ and $20 \%$ solids loadings at four different enzyme concentrations: (a) cellulose conversion and and (b) glucose values in $\mathrm{g} \mathrm{L}^{-1}$ as hydrolyzed. Pretreatment was performed at $10 \%$ solids loadings with $10 \mathrm{~g} \mathrm{NaOH}$ per $100 \mathrm{~g} \mathrm{CS}$ at $25^{\circ} \mathrm{C}$ for $24 \mathrm{~h}$ (these are different conditions from those used in fig. 3). Hydrolysis was performed for $96 \mathbf{h}$. The biomass was neutralized following pretreatment by thoroughly washing with water. The protein contents listed in the legend correspond to enzyme applications of $15,30,45$ and $60 \mathrm{FPU} \mathrm{g}^{-1} \mathrm{solids}$, respectively. Error bars indicate standard deviations. 
was observed. Selig et al. (2012) also investigated some common compounds used as preservatives in commercial enzyme preparations (glycerol and sorbitol). These preservatives negatively impacted cellulose conversion ( $5 \%$ solids loading), reducing conversion of pure cellulose by $15 \%$ when sorbitol was present at $25 \mathrm{mg} \mathrm{mL}^{-1}$ of hydrolyzate liquid (500 mg sorbitol $\mathrm{g}^{-1}$ cellulose) compared to when no sorbitol was present. Conversion of pure cellulose was reduced by as much as $40 \%$ when sorbitol was present at $160 \mathrm{mg} \mathrm{mL}^{-1}$ hydrolyzate liquid (3,200 $\mathrm{mg} \mathrm{g}^{-1}$ cellulose, or approximately $30 \mathrm{FPU} \mathrm{g}^{-1}$ solids). This sorbitol concentration would be found in an enzyme loading $\sim 6$ times higher than the highest enzyme loading examined in the present study at the same solids loading.

According to another study that characterized multiple commercial enzyme preparations (Nieves et al., 1997), the cellulase system produced from $T$. reesei and marketed as Celluclast $1.5 \mathrm{~L}$ (the enzyme preparation used in this current work) contained $\sim 280 \mathrm{mg}$ sorbitol $\mathrm{mL}^{-1}$ enzyme preparation. The protein content and specific activity of the commercial cellulase preparation surveyed by Nieves et al. (1997) were very similar to the measurements obtained in the present study (data not shown).

Enzymatic hydrolysis experiments were repeated at 5\% and $20 \%$ solids loading using increasing amounts of commercial enzyme (15, 30, 45, and $60 \mathrm{FPU} \mathrm{g}^{-1}$ solids) to determine if a systematic reduction in cellulose conversion would result. Assuming that a similar sorbitol concentration as reported by Nieves et al. (1997) was present in the enzyme preparation used in the present study translated to an application of $\sim 120$ to $500 \mathrm{mg}$ sorbitol g ${ }^{-1}$ cellulose for enzyme applications of 15 to $60 \mathrm{FPU} \mathrm{g}^{-1}$ solids ( 82 to $328 \mathrm{mg}$ protein $\mathrm{g}^{-1}$ cellulose) on $5 \%$ solids loadings (fig. 4). Increasing the sorbitol concentration from 120 to $500 \mathrm{mg} \mathrm{g}^{-1}$ cellulose in combination with the enzyme (protein) concentration from 82 to $328 \mathrm{mg} \mathrm{g}^{-1}$ cellulose reduced the conversion of cellulose in PCS by nearly $70 \%$ and $30 \%$ at $5 \%$ and $20 \%$ solids loadings, respectively. The concurrent application of high sorbitol concentrations with increasing enzyme activities would appear to explain the low cellulose conversions observed in the hydrolysis studies presented here.

Sorbitol is used as a stabilizer in commercial enzyme preparations, which suggests the need for on-farm enzyme production and immediate use for hydrolysis, or finding a different stabilizer for use in commercial enzyme preparations that does not interfere with biomass hydrolysis.

\section{CONCLUSIONS}

The use of high-solids loadings in pretreatment followed by high-solids enzymatic hydrolysis has been proposed for on-farm use as a solution to increase the glucose concentration in the hydrolysate and the subsequent ethanol production. However, the impact of solids loadings of the two unit operations in succession (pretreatment and hydrolysis) on cellulose conversion has not been investigated until now. This study found that high-solids loadings in pretreatment followed by high-solids hydrolysis reduced cellulose conversion efficiency but resulted in the highest glucose concentration in the hydrolysate, which translates to higher al- cohol concentrations in the fermentation and therefore lower product recovery costs. Increasing the $\mathrm{NaOH}$ loading and pretreatment time did not improve cellulose conversion efficiency when high-solids loadings were used in both unit operations. However, increasing enzyme dosage improved cellulose conversion from $9.6 \%$ to $36.8 \%$ when high-solids loadings were used in both unit operations. The higher enzyme-to-substrate ratio had a larger impact on cellulose conversion than the pretreatment conditions investigated. Using higher concentrations of commercial cellulase preparations introduces soluble inhibitors that can have a significant impact on high-solids hydrolysis. These results could have implications for on-farm processing, such as necessitating the use of enzymes produced on-site without soluble inhibitors.

\section{ACKNOWLEDGEMENTS}

The authors gratefully acknowledge the financial support of the USDA-NIFA Biomass Research and Development Initiative (Grants No. 11000000836 and No. 2011-1000630363). The investigation reported in this study is a part of a project of the Kentucky Agricultural Experiment Station (No. 16-05-087) and is published with the approval of the director.

\section{REFERENCES}

Adney, B., \& Baker, J. (1996). Measurement of cellulase activities. Laboratory analytical procedure. Golden, CO: National Renewable Energy Laboratory.

Banerjee, G., Car, S., Liu, T., Williams, D. L., Meza, S. L., Walton, J. D., \& Hodge, D. B. (2012). Scale-up and integration of alkaline hydrogen peroxide pretreatment, enzymatic hydrolysis, and ethanolic fermentation. Biotech. Bioeng., 109(4), 922-931. https://doi.org/10.1002/bit.24385

Banerjee, G., Car, S., Scott-Craig, J. S., Hodge, D. B., \& Walton, J. D. (2011). Alkaline peroxide pretreatment of corn stover: Effects of biomass, peroxide, and enzyme loading and composition on yields of glucose and xylose. Biotech. Biofuels, 4(1), 1. https://doi.org/10.1186/1754-6834-4-16

Banerjee, S., Mudliar, S., Sen, R., Giri, B., Satpute, D., Chakrabarti, T., \& Pandey, R. A. (2010). Commercializing lignocellulosic bioethanol: Technology bottlenecks and possible remedies. Biofuels Bioprod. Biorefin., 4(1), 77-93. https://doi.org/10.1002/bbb.188

Banerjee, U. C., Chisti, Y., \& Moo-Young, M. (1995). Effects of substrate particle size and alkaline pretreatment on protein enrichment by Neurospora sitophila. Resour. Conserv. Recycl., 13(2), 139-146. http://dx.doi.org/10.1016/0921-3449(94)000435

Cara, C., Moya, M., Ballesteros, I., Negro, M. J., Gonzalez, A., \& Ruiz, E. (2007). Influence of solid loading on enzymatic hydrolysis of steam exploded or liquid hot water pretreated olive tree biomass. Proc. Biochem., 42(6), 1003-1009. https://doi.org/10.1016/j.procbio.2007.03.012

Chen, M., Zhao, J., \& Xia, L. (2009). Comparison of four different chemical pretreatments of corn stover for enhancing enzymatic digestibility. Biomass Bioenergy, 33(10), 1381-1385. https://doi.org/10.1016/j.biombioe.2009.05.025

Cheng, Y.-S., Zheng, Y., Yu, C. W., Dooley, T. M., Jenkins, B. M., \& VanderGheynst, J. S. (2010). Evaluation of high-solids alkaline pretreatment of rice straw. Appl. Biochem. Biotech., 162(6), 1768-1784. https://doi.org/10.1007/s12010-010-8958-4 Cui, Z., Shi, J., Wan, C., \& Li, Y. (2012). Comparison of alkaline- 
and fungi-assisted wet storage of corn stover. Bioresour. Tech., 109, 98-104. https://doi.org/10.1016/j.biortech.2012.01.037

Duguid, K. B., Montross, M. D., Radtke, C. W., Crofcheck, C. L., Wendt, L. M., \& Shearer, S. A. (2009). Effect of anatomical fractionation on the enzymatic hydrolysis of acid and alkaline pretreated corn stover. Bioresour. Tech., 100(21), 5189-5195. https://doi.org/10.1016/j.biortech.2009.03.082

Eronen, P., Österberg, M., \& Jääskeläinen, A.-S. (2009). Effect of alkaline treatment on cellulose supramolecular structure studied with combined confocal Raman spectroscopy and atomic force microscopy. Cellulose, 16(2), 167-178.

https://doi.org/10.1007/s10570-008-9259-8

Ezeji, T. C., Qureshi, N., \& Blaschek, H. P. (2004). Butanol fermentation research: Upstream and downstream manipulations. Chem. Record, 4(5), 305-314. https://doi.org/10.1002/tcr.20023

Gupta, R., \& Lee, Y. Y. (2010). Pretreatment of corn stover and hybrid poplar by sodium hydroxide and hydrogen peroxide. Biotech. Prog., 26(4), 1180-1186. https://doi.org/10.1002/btpr.405

Hendriks, A. T. W. M., \& Zeeman, G. (2009). Pretreatments to enhance the digestibility of lignocellulosic biomass. Bioresour. Tech., 100(1), 10-18. https://doi.org/10.1016/j.biortech.2008.05.027

Hodge, D. B., Karim, M. N., Schell, D. J., \& McMillan, J. D. (2008). Soluble and insoluble solids contributions to high-solids enzymatic hydrolysis of lignocellulose. Bioresour. Tech., 99(18), 8940-8948. https://doi.org/10.1016/j.biortech.2008.05.015

Humbird, D., Mohagheghi, A., Dowe, N., \& Schell, D. J. (2010). Economic impact of total solids loading on enzymatic hydrolysis of dilute acid-pretreated corn stover. Biotech. Prog., 26(5), 1245-1251. https://doi.org/10.1002/btpr.441

Isroi, R. M., Syamsiah, S., Niklasson, C., Cahyanto, M. N., Ludquist, K., \& Taherzadeh, M. J. (2011). Biological pretreatment of lignocelluloses with white-rot fungi and its applications: A review. BioResoures, 6(4), 5224-5259.

Jørgensen, H., Kristensen, J. B., \& Felby, C. (2007a). Enzymatic conversion of lignocellulose into fermentable sugars: Challenges and opportunities. Biofuels Bioprod. Biorefin., 1(2), 119-134. https://doi.org/10.1002/bbb.4

Jørgensen, H., Vibe-Pedersen, J., Larsen, J., \& Felby, C. (2007b). Liquefaction of lignocellulose at high-solids concentrations. Biotech. Bioeng., 96(5), 862-870. https://doi.org/10.1002/bit.21115

Jurgens, G., Survase, S., Berezina, O., Sklavounos, E., Linnekoski, J., Kurkijarvi, A., ... Granström, T. (2012). Butanol production from lignocellulosics. Biotech. Lett., 34(8), 1415-1434. https://doi.org/10.1007/s10529-012-0926-3

Klein-Marcuschamer, D., \& Blanch, H. W. (2015). Renewable fuels from biomass: Technical hurdles and economic assessment of biological routes. AIChE J., 61(9), 2689-2701. https://doi.org/10.1002/aic.14755

Kristensen, J. B., Felby, C., \& Jorgensen, H. (2009a). Determining yields in high-solids enzymatic hydrolysis of biomass. Appl. Biochem. Biotech., 156(1), 127-132. https://doi.org/10.1007/s12010-008-8375-0

Kristensen, J. B., Felby, C., \& Jorgensen, H. (2009b). Yielddetermining factors in high-solids enzymatic hydrolysis of lignocellulose. Biotech. Biofuels, 2(1), 11. https://doi.org/10.1186/1754-6834-2-11

Larsen, J., Østergaard Petersen, M., Thirup, L., Wen Li, H., \& Krogh Iversen, F. (2008). The IBUS process: Lignocellulosic bioethanol close to a commercial reality. Chem. Eng. Tech., 31(5), 765-772. https://doi.org/10.1002/ceat.200800048

Lau, M. W., \& Dale, B. E. (2009). Cellulosic ethanol production from AFEX-treated corn stover using Saccharomyces cerevisiae 424A(LNH-ST). Proc. Natl. Acad. Sci., 106(5), 1368-1373. https://doi.org/10.1073/pnas.0812364106

Liong, Y. Y., Halis, R., Lai, O. M., \& Mohamed, R. (2012). Conversion of lignocellulosic biomass from grass to bioethanol using materials pretreated with alkali and the white rot fungus Phanerochaete chrysosporium. BioResoures, 7(4), 5500-5513. https://doi.org/10.15376/biores.7.4.5500-5513O

Luterbacher, J. S., Tester, J. W., \& Walker, L. P. (2010). Highsolids biphasic $\mathrm{C}_{2}-\mathrm{H}_{2} \mathrm{O}$ pretreatment of lignocellulosic biomass. Biotech. Bioeng., 107(3), 451-460. https://doi.org/10.1002/bit.22823

Mittal, A., Katahira, R., Himmel, M. E., \& Johnson, D. K. (2011). Effects of alkaline or liquid ammonia treatment on crystalline cellulose: Changes in crystalline structure and effects on enzymatic digestibility. Biotech. Biofuels, 4(1), 41. https://doi.org/10.1186/1754-6834-4-41

Modenbach, A. A., \& Nokes, S. E. (2013). Enzymatic hydrolysis of biomass at high-solids loadings: A review. Biomass Bioenergy, 56, 526-544. https://doi.org/10.1016/j.biombioe.2013.05.031

Modenbach, A. A., \& Nokes, S. E. (2014). Effects of sodium hydroxide pretreatment on structural components of biomass. Trans. ASABE, 57(4), 1187-1198. https://doi.org/10.13031/trans.57.10046

Nieves, R. A., Ehrman, C. I., Adney, W. S., Elander, R. T., \& Himmel, M. E. (1997). Survey and analysis of commercial cellulase preparations suitable for biomass conversion to ethanol. World J. Microbiol. Biotech., 14(2), 301-304. https://doi.org/10.1023/a:1008871205580

Peterson, G. L. (1977). A simplification of the protein assay method of Lowry et al. which is more generally applicable. Anal. Biochem., 83(2), 346-356.

Rabelo, S. C., Andrade, R. R., Maciel Filho, R., \& Costa, A. C. (2014). Alkaline hydrogen peroxide pretreatment, enzymatic hydrolysis, and fermentation of sugarcane bagasse to ethanol. Fuel, 136, 349-357. https://doi.org/10.1016/j.fuel.2014.07.033

Romsaiyud, A., Songkasiri, W., Nopharatana, A., \& Chaiprasert, P. (2009). Combination effect of $\mathrm{pH}$ and acetate on enzymatic cellulose hydrolysis. J. Environ. Sci., 21(7), 965-970. http://dx.doi.org/10.1016/S1001-0742(08)62369-4

Selig, M., Weiss, N., \& Ji, Y. (2008). Enzymatic saccharification of lignocellulosic biomass. Laboratory analytical procedure. Golden, CO: National Renewable Energy Laboratory.

Selig, M., Hsieh, C., Thygesen, L., Himmel, M., Felby, C., \& Decker, S. (2012). Considering water availability and the effect of solute concentration on high-solids saccharification of lignocellulosic biomass. Biotech. Prog., 28(6), 1478-1490. http://dx.doi.org/10.1002/btpr.1617

Sills, D. L., \& Gossett, J. M. (2012a). Using FTIR spectroscopy to model alkaline pretreatment and enzymatic saccharification of six lignocellulosic biomasses. Biotech. Bioeng., 109(4), 894-903. https://doi.org/10.1002/bit.2437

Sills, D. L., \& Gossett, J. M. (2012b). Using FTIR to predict saccharification from enzymatic hydrolysis of alkali-pretreated biomasses. Biotech. Bioeng., 109(2), 353-362. https://doi.org/10.1002/bit.23314

Singhania, R. R., Patel, A. K., Soccol, C. R., \& Pandey, A. (2009). Recent advances in solid-state fermentation. Biochem. Eng. J., 44(1), 13-18. https://doi.org/10.1016/j.bej.2008.10.019

Sluiter, A., Ruiz, R., Scarlata, C., Sluiter, J., \& Templeton D. (2005). Determination of extractives in biomass. Laboratory analytical procedure. Golden, CO: National Renewable Energy Laboratory.

Sluiter, A., Hames, B., Hyman, D., Payne, C., Ruiz, R., Scarlata, C., ... Wolfe, J. (2008a). Determination of total solids in biomass and total dissolved solids in liquid process samples. Laboratory 
analytical procedure. Golden, CO: National Renewable Energy Laboratory.

Sluiter, A., Hames, B., Ruiz, R., Scarlata, C., Sluiter, J., Templeton, D., \& Crocker, D. (2008b). Determination of structural carbohydrates and lignin in biomass. Laboratory analytical procedure. Golden, CO: National Renewable Energy Laboratory.

Triwahyuni, E., Sudiyani, Y., \& Abimanyu, H. (2015). The effect of substrate loading on simultaneous saccharification and fermentation process for bioethanol production from oil palm empty fruit bunches. Energy Procedia, 68, 138-146. http://dx.doi.org/10.1016/j.egypro.2015.03.242

Viamajala, S., Donohoe, B. S., Decker, S. R., Vinzant, T. B., Selig, M. J., Himmel, M. E., \& Tucker, M. P. (2010). Heat and mass transport in processing of lignocellulosic biomass for fuels and chemicals. In O. V. Singh \& S. P. Harvey (Eds.), Sustainable biotechnology: Sources of renewable energy (pp. 1-18).
Dordrecht, The Netherlands: Springer. https://doi.org/10.1007/978-90-481-3295-9_1

Wan, C., Zhou, Y., \& Li, Y. (2011). Liquid hot water and alkaline pretreatment of soybean straw for improving cellulose digestibility. Bioresour. Tech., 102(10), 6254-6259. https://doi.org/10.1016/j.biortech.2011.02.075

Xu, J., Cheng, J. J., Sharma-Shivappa, R. R., \& Burns, J. C. (2010). Sodium hydroxide pretreatment of switchgrass for ethanol production. Energy Fuels, 24(3), 2113-2119. https://doi.org/10.1021/ef9014718

Zhang, Y., Liu, Y.-Y., Xu, J.-L., Yuan, Z.-H., \& Zhuang, X.-S. (2011). High solids and low enzyme loading based saccharification of agricultural biomass. BioResoures, 7(1), 345353. 